\title{
Innovative CSR Models in IT Sector
}

\section{* Ms. Minimol}

\section{Abstract}

Every organization utilises the resources available in the society or environment to maximize their profit and it is the responsibility of the organisation to contribute something in return, which can be referred to be as CSR or Corporate Social Responsibility. It is a part of activities for every organisation where it is said to be the effort made by the corporate in developing the society. Now a days, innovations on CSR model are treated as the foundation of business competencies. This has emerged gradually over past decades where improvement in CSR refers to social innovation. And over the period, organizations' activities and strategies are becoming more and more social responsible

Company should do something more than monetary measures to solve the issues like poverty, education, healthcare development etc. Making use of these challenges provide an opportunity for growth.

The present study has been made on top four IT companies in India, where the innovation on CSR activities are focused. Likewise the paper will also take into consideration, the new innovations that can be brought by companies for social benefits and sustainable development.

Keywords: Corporate Social Responsibility, Innovations, Social innovations

\section{Introduction}

Corporate Social Responsibility is not a new area of study, but recently it is gaining attention, interest and value among companies, media, government, research and NGO'S. Most of the companies consider CSR as a main business strategy. Earlier it was some corporates who willingly contributed to CSR activities by paying a sum of amount for charitable purpose. This cannot be considered as CSR activity, since these corporates have undertaken these activities

\footnotetext{
* First year Student, A. J. Institute of Management, Mangaluru
} 
for saving the tax and for fame, but India made it mandatory by law in Companies Act 2013 under section 135 in its seventh schedule of the Act, where the company with Rs. 500 crore or more net worth or with Rs. 1000 crore turnover or with Rs. 5 crore net profit must contribute minimum two percent of their net profit to CSR activities and they must also have a CSR committee for the same. This came into effect since 1 April 2014. CSR activities include eradicating hunger, poverty, malnutrition, providing healthcare, education, employment enhancing vocational skills, slum area development, rural development programme, swachh bharath, clean Ganga mission and so on.

Giving a precise definition to CSR is not an easy task. There is no one such single definition that can be called as practicable to be used and one may not fit for all. According to Lord Holme and Richard Watts in the article "Making Good Business Sense" published by World Business Council for Sustainable Development defines Corporate Social Responsibility as "the continuing commitment by business to behave ethically and contribute to economical development while improving the quality of life of the workforce and their families as well as of the local community and society at large"

CSR contains social, economical and environmental development. Social impact consists of involvement in external social issues such as education, social inclusion, generation and employee volunteering. Economic impact consists of addressing issues relating to jobs, ethical training standards and product value. Environment impact consists of consideration of emissions and waste control, energy use, product life cycle and sustainable development.

Innovation on CSR: It has a positive impact on the performance of an organization where there is a link between CSR related practices and also innovation. Many corporates in order to keep their competitive position in a globalizing world economy have flagged great aspiration regarding innovation. Innovation is stimulated not only by new technologies, the development of engineering skills 
and demands of the consumers, but also by a considerable global concern for CSR issues. Inorder to be successful and innovative nowadays, the companies must look into the view of social, economical and environmental impact on their operational processes, stimulate the creativity of their workforce, and cooperate with their stakeholders in designing and developing new and innovative products and services. Innovation is one of the main drivers for competitiveness, yet it is far from easy to achieve. Evidences suggest that 'though innovative effort appears to be widespread, this does not translate directly into improved firm performance and, ultimately, greater probability'. Today, being a successful and innovative, the business requires consideration of the social and environmental impact of operational processes, stimulating employees to be creative and collaborating with customers, suppliers and other business partners in the design and development of new products and services.

Social innovation: It refers to the creation, development, adoption, and integration of new and renewed concepts, systems, and practices that put people and planet first and deploying effective solution to challenging and often systemic social and environmental issues in support of social progress. The concept of social innovation focuses attention on the ideas and solutions that create social value, as well as the process through which they are generated, regardless of where they are coming from.

\section{Literature Review}

CSR innovation is crucial and inevitable for every entity. Also nowadays companies seem to favour socially responsible solutions. According to scientific evidence social responsibility positively influences a company's performance inter alia by increasing reputation (Lou and Bhattacharya 2006). Therefore it seems essential for companies to improve synergic effect between the two concepts.

Nowadays, the notion of innovation refers to the process of implementing positive and new ideas to business practice (Szutowski 2016). Innovation represents a significant component of a company's strategy as it determines the direction of the firms' evolution (Siguaw, 
2009). Furthermore its role is stimulating market value increase is well documented (Rubera and Kirca, 2012). The definition of CSR was formulated as "the responsibility of enterprises for their impact on society" with the aim of "maximizing the creation of shared value for their owners/shareholders and for their other stakeholders and society at large" (European commission, 2011). The most important shifts lies in the purpose of CSR that appears to be value maximization achieved by the introduction of innovative products, services and business models. By and large the scientific community seems to reject a philanthropic or marketing attitude to CSR and follows the trend developed in recent years that needs to be linked to the modification of business models and concentration on innovation (Visser, 2010). In other words, companies should implement innovative production to transform the impact of its business activities on society.

Innovation may occur in every field of business activity, which results in its strong diversity. The most common approach of classifying innovation is perhaps the one proposed in the Oslo Manual (OECD and Eurostat, 2005). It covers four types of innovations: product, process, organisational and marketing, each of which is marked by socially responsible aspects differently. While the principal benefits of new socially responsible products seems to be increased consumer satisfaction, the main advantages of socially responsible processes manifests through the reduced use of resources and cost cutting (Tidd. 2001). Also new organisational structures, which involve improved work conditions, are better received by staffs. The second basic classification of innovation covers the degree of novelty involved in it. Such classification consists of three categories: incremental, new to the company and radical innovation (Tidd, Bessant and Pavitt, 2005). From the point of view of social responsibility radical innovation seem to entail most advantages as its effect spread over both the company and its surroundings

Governments want to implicit policies that support firm's environmentally and socially responsible behaviour (Wagner, 2010) looking to increase international competitiveness, sustainable 
development and economic growth. While innovation has been recognised as one of the key elements to increase competitiveness, it may be also one of the most effective ways to increase corporate social performance. There is case-based evidence showing this type of approach may produce the highest potential benefit for both the firm and the society (Halme and Laurila, 2009). CSR has become of greater practical significance to increase competitiveness for firms and governments alike. Firms engage on CSR practices aiming to improve corporate social performance and financial performance. Governments want to implicit policies that support firm's environmentally and socially responsible behaviour (Wagner, 2010) looking to increase international competitiveness, sustainable development and economic growth. For example, the European Commison sees CSR as an important part of the European strategy for increasing growth, competitiveness, quality of jobs (Lisbon stratergy) and sustainable development (Gothenburg strategy).

Porter and Kramer (2006) characterise the various levels according to the firms "strategic intent" (Hamel, 2001). They, then established the link between each type of CSR and firm innovation performance. However, nothing is said on the CSR practices and their characteristics. We therefore aim to complete this framework by a better characterisationof CSR profiles.

\section{Research Methodology}

On the basis of their revenue, top IT companies in India, TCS, Infosys, Tech Mahindra and Wipro have been selected for the present study. The analysis has been done on the basis of secondary data collected from various journals, magazines, annual reports of sample companies.

\section{Objectives}

1. To know their Corporate Social Responsibility in the context of innovation.

2. To analise the expected spending and the actual spending on CSR activites.

3. To determine the impact of innovation in the field of CSR with 
that of the previous financial years.

\section{Limitations}

- The study is based on the four IT Companies by its revenue and thus the performance level of these companies may vary one to another and also to that of the whole IT industry.

- Inadequate availability of data is another limiting factor which might have affected the analysis of data to some extent. However care has been taken to minimize its effects through collection of required information from various informal and formal methods.

- The limited time at the disposal of the researcher has some effect on the quality of the present study.

\section{CSR and innovation in IT industry}

The leading and top IT companies in India are considered and the parameters like net sales and number of employees in the organisations are considered. The final evaluation has been done on the basis of the revenue.

\section{TCS}

- TCS or Tata Consultancy Company has become the first Indian IT company to have a market capitalization of 100 billion dollars. They have net sales at Rs. 9512 cr. The guiding principle of CSR programme of TCS is "Impact through Empowerment". The policy also aims at demonstrating care for the community through its focus on education and skill development, health and wellness and environmental sustainability including bio-diversity, energy and water conservation. They have came up with the following social initiatives and innovations in the field of CSR activities.

- Education and skill building like Adult Literacy Programme, free healthcare facilities, special education, childline software support to track missing children. Affirmitive actions like training programmes for marginalised youth across India, are directed towards SC/ST communities as defined by the 
Government of India.

- Aiding under-privileged children, helping rural community in Vazapur, HIV and AIDS sensitization, employement oppurtunities for the differently-abled, peer education and Green Audits, Disaster Relief, technical support for Hospitals including cancer institute, promoting hygiene sanitation. Eradicating hunger poverty and malnutrition, contribution to Swatchh Bharat Kosh set up by the Central Government. Water conservation through desilting, repair and maintenance of lakes,watershed restoration for sustainability and flood protection.

Total income of TCS for the Financial Year 2017-18 is Rs. 1,13,159 cr. and during the prvious year it was Rs. $97,261 \mathrm{cr}$. The TCS has a composition of CSR Committee with Directors comprising Mr. M N Chandrashekaran, Chairman of the committee, Mr. O P. Bhatt, Mr. Rajesh Gopinathan and Ms. Aarathi Subramanian. Average net profit of the company for the last three financial years for the purpose of computation of CSR is Rs. $24,868 \mathrm{cr}$, where prescribed CSR Expenditure is Rs. $497 \mathrm{cr}$. Where the amount unspend is Rs. $97 \mathrm{cr}$.

The company has failed to spend two percent of the average net profits of the last three financial years.

The Company spent Rs. $379.71 \mathrm{cr}$. on CSR programmes during the financial year 2016-17 as against the prescribed CSR expenditure of Rs. 466 cr.

\section{INFOSYS}

Infosys is a household name of Information Technology space with workforce of two lakh people in different countries. They have net sales of Rs. $60878 \mathrm{cr}$. They established the Infosys Foundation in 1996 as a non-profit nodal body aimedat providing a dedicated approach to community development and also to fulfil their CSR commitment. They strive for economic development that positively impacts the society at large with minimal resources footprint. Their CSR activites include:

- Eradicating extreme hunger, poverty,and malnutrition, 
promoting preventive healthcare and sanitation and making available safe drinking water.

- Promoting education, including special education and employment enhancing vocational skills especially among childen, women, elderly and the differently abled, and livelihood enhancement projects; monetary contribution to academic institution for establishing endownment funds, chairs, laboratory etc., with the objective of assessing students in their studies.

- Strengthening rural areas by improving accessibility, housing, drinking water, sanitation, power and livelihood, there by creating sustainable villages.

- Promoting gender equality and empowering women; setting up homes hostels and day care centers for women and orphans; setting up of old age homes and such other facilities for senior citizens; and adopting measures for reducing inequalities faced by the socially and economically backward group. It also includes environmental sustainability, protecting national heriage, art and culture.

Total net profit of Infosys has increased by 6.4 percent to Rs. 14,353 cr for the year ended March 31, 2017 as against Rs. 13,489 cr in the previous year. The CSR Committee comprises two independend Directors and CEO and MD as members. As on March 31, 2017, The Committee had R Seshasayee as Chairperson and Kiran Mazmudarshaw, Dr. Vishal Sikka as members. While aiming at generating maximum profit for the shareholder, they also focus on their social and environmental responsibility to fulfil the needs and expectations of the community. It is not limited to philanthrophy, but encompasses holistic community development, institutional building and sustainability related initiatives. It was set up to formulate and monitor the CSR policy of the company. The following Table provides a birdsview of financial details of CSR of the company. 
Table No. 1 : CSR Financial Details(INR cr)

\begin{tabular}{|l|r|r|r|}
\hline \multicolumn{1}{|c|}{ Year } & \multicolumn{1}{c|}{$\mathbf{2 0 1 5 - 1 6}$} & \multicolumn{1}{c|}{$\mathbf{2 0 1 6 - 1 7}$} & \multicolumn{1}{c|}{$\mathbf{2 0 1 7 - 1 8}$} \\
\hline Actual CSR & 202.30 & 202.30 & 202.30 \\
\hline Prescribed CSR & 202.30 & 202.30 & 202.30 \\
\hline
\end{tabular}

Source: Companies Annual Reports

It can be observed that the company has spent during all the years more than the prescribed fund for CSR acuities.

\section{TECH MAHINDRA}

Tech Mahindra is a part of Mahindra group, which is one of the most reputed organisations in India. It has a net sales of Rs. 23,562 cr. during 2017-18. The CSR vision of Tech Mahindra is "Empowerment through Education". For them CSR means responsible business practices through the involvement of all stakeholders in the decision making process and in operations. It entails having business policies that are ethical, equitable, environmentally conscious, gender sensitive and sensitive towards the differently abled. The company implements its CSR programmes through its two institutions; Tech Mahidnra Foundation, Mahindra Educational Institutions.

The CSR Committee of Tech Mahindra consists of three or more directors out of which one will be an Independent Director.

Education is the tool for creating an empowerd, enlightened society capable of rising to its full potential.Availability of quality education for all classes is the way to ensure an equitable and just social system.

The companies CSR activities included the following

- Supporting to the Government of Indias larger vision of skill development of youth through developing their market oriented skills and linking them to potencial employers. This helps school drop out, people with disabilities, and those enable to go into higher education, among other with specific focus on women

- Initiative to establish institution of higher learning, promote research and development and collaborate with other renowened institution to contribute towards the goal of high 
quality technical education systems in India.

Total reported Net Profit of the financial year 2017-18 is Rs. 3,999.30 cr. as against Rs. 3,047.37 cr during the previous year. The prescribed spending on CSR is Rs. 71.55 cr. and the actual spending is Rs. 76.42 cr. for the year 2017-18. The relative figures for the previous years were Rs. 60.82 cr. and Rs. 62.33 cr.

The CSR financial details of Tech Mahindra can be seen in the following Table.

Table No. 2 : CSR Financial details of Tech Mahindra

\begin{tabular}{|l|r|r|r|}
\hline \multicolumn{1}{|c|}{ Year } & \multicolumn{1}{c|}{$\mathbf{2 0 1 5 - 1 6}$} & \multicolumn{1}{c|}{$\mathbf{2 0 1 6 - 1 7}$} & \multicolumn{1}{c|}{$\mathbf{2 0 1 7 - 1 8}$} \\
\hline Actual CSR & 46.91 & 62.33 & 76.42 \\
\hline Prescribed CSR & 41.40 & 60.82 & 71.55 \\
\hline
\end{tabular}

Source: Companies Annual Reports

In the case of Tech Mahindra also it can be observed that during the above period the Company spent funds more thefunds prescribed for CSR activities.

\section{WIPRO}

Wipro was initially set up as Western India Vegetable Product Limited in 1945 by Mr. Aziz Premji's father as vegetable oil trading company. In 1966 Aziz Premji took over a leadership and transformed the company into consumer goods company. In 1979 it developed its own computer and later moved into software development organisation.

Wipros' engagement with social and ecological issues goes back a long time. The central tenets of the company have been the emphasis on strong, meaningful work on systematic social issues.

Given below the companies CSR activities which reflect their concern about the social respobsibility of the company.

- Engaging in deep and meaningful systematic work in the area of school and college education, educating for children with disability, and sustainability education.

- Community ecology and health care, where engaging with 
the community on issues of healthcare, eocology and education for the under previlaged

- Reducing and minimizing the environmental footprint of company's operations and enhancing the bio diversity quotient of company's facilities.

- Encouraging and enhancing diversity at the workplace and outside on gender, nationality and persons with disability. The CSR activies of Wipro are carried out through a trust focusing on certain key development issues. The trust is formed in 2003.

Total reported profit of Wipro for the financial year 2017-2018 is Rs. $80,081 \mathrm{cr}$. as against its previous financial year profit of Rs. $84895 \mathrm{cr}$.

Table No. 3: CSR Fund Financial Details

\begin{tabular}{|l|r|r|r|}
\hline \multicolumn{1}{|c|}{ Year } & \multicolumn{1}{c|}{$\mathbf{2 0 1 5 - 1 6}$} & \multicolumn{1}{c|}{$\mathbf{2 0 1 6 - 1 7}$} & \multicolumn{1}{c|}{$\mathbf{2 0 1 7 - 1 8}$} \\
\hline Actual CSR & 159.80 & 186.30 & 186.00 \\
\hline Prescribed CSR & 156.00 & 176.40 & 183.30 \\
\hline
\end{tabular}

Source: Companies Annual Reports

As shown in the above Table the company as spent more than the prescribed CSR buedget during the last three financial years.

\section{Findings}

- While considering the innovation in CSR field with reference to the sample companies, it can be observed that there are many social innovations happening every now and then. While looking deep into the aspects, It can be noted that majority of the companies under study have come up with contributions like mainly to education field, rural development and healthcare.

- The companies contribute a lot to innovations in CSR activities, as they are utilising the resources from the society and it is their responsibility to give something for the social development. Though India made it mandatory for the corporates earning huge profit, they find many loop holes in 
the act and its implementation.

- The four sample companies differ with regard to their spending under CSR activities. The analysis has shown that the sample companies have spent on CSR activities more than the prescribed amount.

- As stated by the Companies under study, the reason for variation between the spending and budgeted amount is due to difference in net profit, turnover and some times due to some genuine reasons beyond the control of the management.

- It has been found that after making the CSR spending a mandatory activity the companies contributions have increased to greate extent.

- The innovations include the training of unskilled labours, teaching the rural students by the company employees, contribution in the field of healthcare, sanitation, awareness on HIV, AIDS, women empowerment etc.

\section{Suggestions}

On the basis of the analysis of data the following suggestions are offered:

- It is not enough if the CSR spending is made mandatory. There is a need to create awareness among the companies. This will go a long way in reducing the cases of avoiding CSR activities finding the loopholes in the Act.

- Companies can also look into the aspects of helping farmers bringing agriculture under CSR concept.

- Companies can build an entity to look into the cases of companies which have spent less than the prescribed limites on CSR activities.

\section{Conclusion}

The paper aims at summarizing the state of knowledge on the relationship between a companys' Corporate Social Responsibility and its innovation performance. The research relied on qualitative analysis of sampling data. The result indicated that the lack of 
scientific analysis and of sample size. CSR was assumed to influence innovation performance, and inversely, innovations presumed to have an impact on the companys' CSR. However, the relations' determinants are strongly diversified

\section{Reference}

Refered articles on J Gate:

"Lessons for Responsible Innovation in the Business Context: A Systematic Liteature Review of Responsible, Social and Sustainable Innovation Practice" by Rob Lubberink, Vincent Blok, John van Opem, and Onno Omta.

"Corporate Social Responsibility (CSR) and Innovation- The Drivers of Business growth?" by Gadaf Rexhepi, Selma Kutrishi, Gjilnaipe Bexheti.

"Baseline Study on CSR in Macedonia", UNDP(2007)

"Innovation in Indian CSR- a Conceptual Model", by Nagaraj M S \& Shalini G

"Responsible Innovation Towards sustainable Development in small and Medium-sized Enterprises: a Resource Perspective", by Halme and Korpela

"The links of sustainable competitiveness and innovation with openness and user integration:An empirical analysis". Wagner

"Responsilble research and innovation: From sciene in society to science for society, with society". Owen, 2012.

"The relationship of communication, ethical work climate, and trust to commitment and innovation." By Ruppel C P, Harrington.

Website:

https://www.innov8social.com

https://www.quora.com

https://www.emeraldinsight.com/doi/abs/10.1108/SAMPJ-072015-0058?fullSc=1\&journalcode=sampj

https://www.socialinnovationexchange.org/insights/25companies-carrying-out-corporate-social-innovation

https://www.infosys.com

https://www.soulace.in

https://www.tcs.com

https://www.wipro.com 